\title{
GLOBUS PHARYNGEUS: A SYMPTOM OF INCREASED THYROID OR LARYNGOPHARYNGEAL REFLUX?
}

\author{
Sani Penović ${ }^{1}, \check{Z ̌ e l j k a ~ R o j e}^{2}$, Dubravka Brdar ${ }^{3}$, Sanda Gračan ${ }^{3}$, Ana Bubić ${ }^{4}$, \\ Jadranka Vela ${ }^{5}$ and Ante Punda ${ }^{3}$
}

${ }^{1}$ University Department of Surgery, Split University Hospital Centre, Split, Croatia;

${ }^{2}$ Private Practice of Otorhinolaryngology, Split, Croatia; ${ }^{3}$ Department of Nuclear Medicine, Split University Hospital Centre, Split, Croatia; ${ }^{4}$ Institute of Emergency Medicine of Split-Dalmatia County, Split, Croatia; ${ }^{5}$ University Department of ENT, Head and Neck Surgery, Split University Hospital Centre, Split, Croatia

\begin{abstract}
SUMMARY - The aim of this study was to investigate the relationship between globus pharyngeus and laryngopharyngeal reflux, as well as between globus and thyroid volume. A two-year prospective study included 56 patients aged 18-75 with globus symptom. Anthropometric, clinical and laboratory data were collected. All patients filled-out the Glasgow Edinburgh Throat Scale (GETS) and then underwent thyroid ultrasound. Morphological changes of the larynx were detected by direct laryngoscopy and classified by the Reflux Finding Score (RFS). If RFS $>7$, the diagnosis of laryngopharyngeal reflux was made and therapy with proton pump inhibitors initiated. According to GETS, there was significant difference between patients with normal volume and those with large thyroid volume. There was no statistically significant difference between patients with RFS $<7$ and RFS $>7$. In conclusion, the incidence and severity of globus pharyngeus do not definitely indicate laryngopharyngeal reflux. It is more common in patients with normal thyroid volume.
\end{abstract}

Key words: Laryngopharyngeal reflux; Pharyngeal diseases; Thyroid gland; Ultrasonography; Proton pump inhibitors; Surveys and questionnaires

\section{Introduction}

Globus pharyngeus is a sensation of having a lump or foreign body in the throat ${ }^{1,2}$. It is a common condition accounting for 3\%-4\% of new otorhinolaryngology outpatient referrals 3 . It is reported by up to $46 \%$ of apparently healthy individuals, with a peak incidence in middle age $e^{4,5}$. This condition is equally prevalent in men and women ${ }^{6}$. Hippocrates first noted it approximately 2500 years $\mathrm{ago}^{7}$. In the past, globus was described as globus hystericus because of its frequent association with menopause or psychogenic factors ${ }^{8}$. In

Correspondence to: Sani Penovic, MD, University Department of Surgery, Split University Hospital Centre, Spinčićeva 1, HR-21000 Split, Croatia

E-mail: sanipenovic@gmail.com

Received March 23, 2016, accepted July 8, 2016
1968, after discovering that most patients experiencing globus did not have a hysterical personality, the more accurate term 'globus pharyngeus' was coined'. The etiology remains elusive. Although data are limited, previous studies investigated links with gastroesophageal reflux disease (GERD) $)^{10-18}$, esophageal dysmotility ${ }^{19}$, abnormalities of the upper esophageal sphincter $^{20}$, temporomandibular joint dysfunction ${ }^{21}$, pharyngeal inflammation ${ }^{22,23}$, enlarged lingual tonsils $^{24}$, upper aerodigestive malignancy ${ }^{7,25}$, psychological factors, and stress ${ }^{26,27}$. As globus cannot be assessed by clinical examination, there is a validated questionnaire, the Glasgow Edinburgh Throat Scale (GETS) that can appraise with high probability the incidence and severity of globus ${ }^{28}$. From the aspect of otorhinolaryngologist, the most important connection of the globus is with thyroid diseases and laryngopharyngeal reflux 
(LPR). LPR is known as direct irritation and inflammation of the laryngopharynx by retrograde flow of gastric contents ${ }^{15,16}$. Globus pharyngeus appears in 95\% of patients with LPR, which is besides throat clearing (98\%), persistent cough (97\%) and hoarseness (95\%), one of the leading symptoms of this disease ${ }^{29}$. The Reflux Finding Score (RFS) validates morphological changes of laryngeal mucosa, which occur as the result of LPR and can be demonstrated by direct laryngoscopy. The changes of the larynx can include subglottic edema, ventricular obliteration, erythema/ hyperemia, vocal fold edema, diffuse laryngeal edema, posterior commissure hypertrophy, granuloma and thick endolaryngeal edema ${ }^{30}$. Each of the mentioned parameters is separately evaluated and the possible score range is from 0 (normal) to 26 (worst possible score). RFS $>7$ indicates a diagnosis of LPR. Some other diagnostic methods for detecting LPR are contrast radiology, 24-hour $\mathrm{pH}$-monitoring, and multichannel intraluminal impedance (MCII) ${ }^{31}$. All these methods are invasive and they are used in cases when empirical treatment fails. The main medication in LPR treatment is proton pump inhibitor (PPI), which diminishes daily production of gastric acid and strengthens sphincter tone. Besides patients suffering from LPR, globus pharyngeus also occurs in $30 \%$ of patients with thyroid pathology ${ }^{1}$. The patients with globus symptom that underwent thyroidectomy had the following histologic diagnoses: multi-nodular and colloid goiter, follicular adenoma, carcinoma, and thyroiditis. The aim of this study was to investigate the cause-andeffect connection between globus pharyngeus and LPR, between globus and thyroid volume, as well as to compare the results obtained in order to administer appropriate treatment to patients with globus pharyngeus.

\section{Patients and Methods}

This cross-sectional prospective two-year study was conducted at the University Department of ENT, Head and Neck Surgery and Department of Nuclear Medicine, Split University Hospital Centre in Split. It included 56 patients aged 18-75 referred by their family physician for diagnostic work-up at Department of Nuclear Medicine for globus symptom. The patients who had globus due to allergic reactions, pharyngeal inflammation and upper aerodigestive malignancy

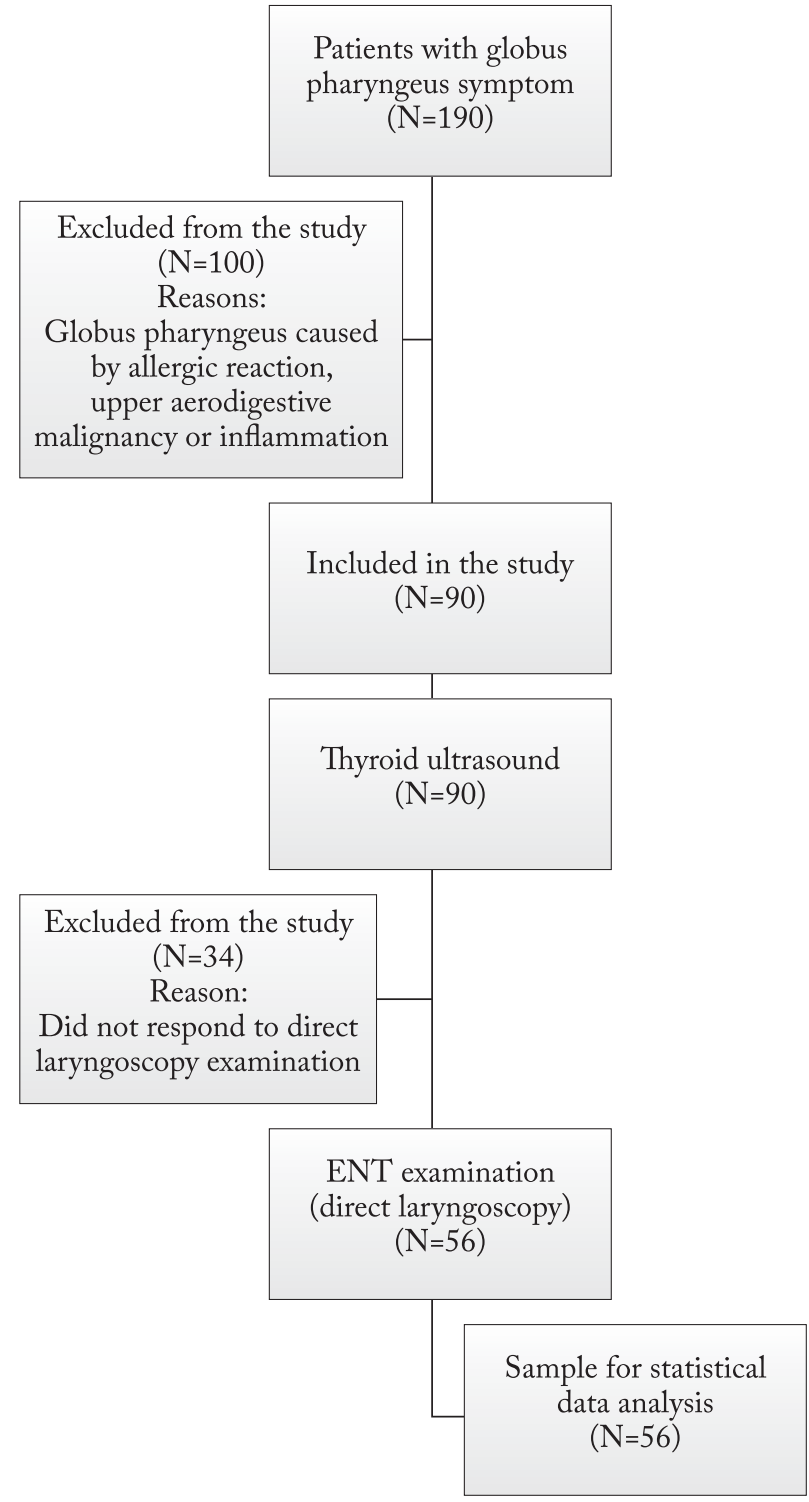

Fig. 1. Study flow diagram.

were excluded. Anthropometric, clinical and laboratory data were collected. Anthropometric data included patient age (years), sex, neck circumference $(\mathrm{cm})$, body weight $(\mathrm{kg})$, height $(\mathrm{m})$ and body mass index $\left(\mathrm{kg} / \mathrm{m}^{2}\right)$. On assessing the severity of globus symptom, data were analyzed by use of GETS, which the patients filled-out at Department of Nuclear Medicine. Each patient was asked to assess the sensation of globus pharyngeus by completing the 10 -item questionnaire about common throat symptoms ${ }^{28}$. Symptom intensity is graded by numbers from 0 (absence of symptoms) to 7 (highest symptom intensity). After completing the 
questionnaire, thyroid ultrasound (Aloka SSD-400 sv, Tokyo, Japan) was performed to determine dimensions of the thyroid (separately left and right lobe and isthmus) in millimeters ( $\mathrm{mm}$ ). The volume of each lobe and isthmus was calculated by the formula: width $(\mathrm{cm})$ $\times$ depth $(\mathrm{cm}) \times$ length $(\mathrm{cm}) \times 0.524$ (correction factor $)^{32}$. The total thyroid volume was the sum of the right lobe volume, left lobe volume and isthmus volume. At the University Department of ENT, direct laryngoscopy was performed to determine RFS. $\mathrm{Pa}-$ tients with RFS $\geq 7$ were diagnosed with LPR and prescribed PPI medication $2 \times 20 \mathrm{mg}$ for at least 3 months (Fig. 1).

The study was approved by the Split University Hospital Centre Ethics Committee and conducted in agreement with the Declaration of Helsinki principles. All the participants signed a written informed consent prior to inclusion in the study.

\section{Statistics}

Statistical analyses were performed using the MedCalc for Windows, version 11.5.1.0 (MedCalc Software, Mariakerke, Belgium) statistical software. Continuous data were presented as mean \pm standard deviation, whereas categorical variables were presented as number and percentage.

\section{Results}

The study included 56 (52 female and four male) patients (Fig. 2). Demographic data of these patients are shown in Table 1 . The most prominent symptoms

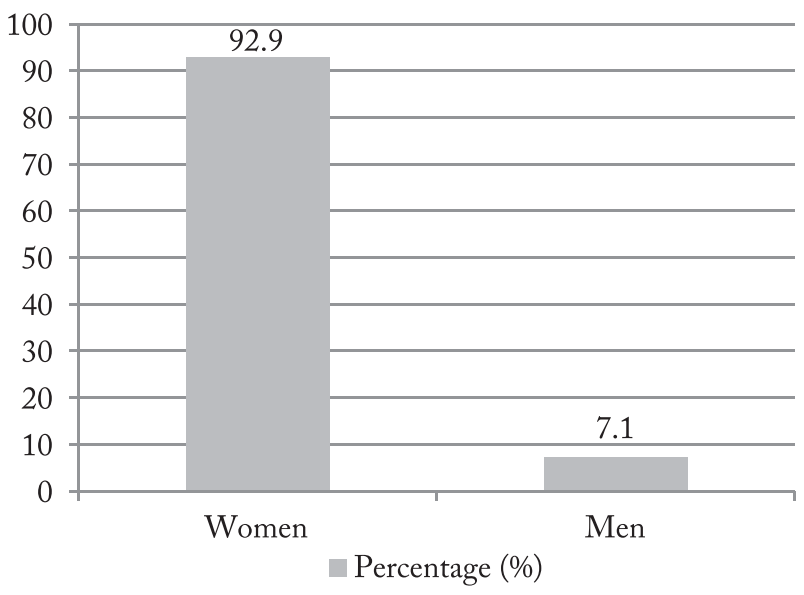

Fig. 2. Patient distribution according to gender.
Table 1. Demographic characteristics of study patients

\begin{tabular}{|l|l|}
\hline & Patients (N=56) \\
\hline Variable & Median (range) \\
Age (years) & $44(20-78)$ \\
Height $(\mathrm{m})$ & $1.69(158-188)$ \\
Weight $(\mathrm{kg})$ & $70(38-100)$ \\
\hline & Mean \pm standard deviation \\
\hline Body mass index $\left(\mathrm{kg} / \mathrm{m}^{2}\right)$ & $24.3 \pm 4.01$ \\
Neck circumference $(\mathrm{cm})$ & $34.5 \pm 2.98$ \\
\hline
\end{tabular}

Table 2. Results on symptoms rated by the Glasgow and Edinburgh Throat Scale

\begin{tabular}{|c|c|c|c|c|}
\hline Symptom & Mean & $\begin{array}{l}\text { Standard } \\
\text { deviation }\end{array}$ & Median & Mode \\
\hline $\begin{array}{l}\text { Feeling } \\
\text { of something } \\
\text { stuck in the throat }\end{array}$ & 4.70 & 1.98 & 5 & 6 \\
\hline Pain in the throat & 2.37 & 1.31 & 2 & 1 \\
\hline $\begin{array}{l}\text { Discomfort/ } \\
\text { irritation } \\
\text { in the throat }\end{array}$ & 3.37 & 1.96 & 3 & 2 \\
\hline $\begin{array}{l}\text { Difficulty in } \\
\text { swallowing food }\end{array}$ & 4.06 & 1.71 & 4 & 3 \\
\hline Throat closes off & 3.88 & 1.97 & 4 & 3 \\
\hline $\begin{array}{l}\text { Swelling } \\
\text { in the throat }\end{array}$ & 3.76 & 2.02 & 4 & 3 \\
\hline $\begin{array}{l}\text { Catarrh } \\
\text { in the throat }\end{array}$ & 3.80 & 1.95 & 4 & 2 \\
\hline $\begin{array}{l}\text { Can't empty } \\
\text { throat when } \\
\text { swallowing }\end{array}$ & 3.60 & 1.44 & 4 & 4 \\
\hline $\begin{array}{l}\text { Wanting to } \\
\text { swallow all the } \\
\text { time }\end{array}$ & 4.27 & 1.83 & 4 & 5 \\
\hline $\begin{array}{l}\text { Food sticking } \\
\text { when swallowing }\end{array}$ & 2.93 & 1.64 & 3 & 3 \\
\hline
\end{tabular}

in GETS were "Feeling of something stuck in the throat", "Want to swallow all the time" and "Difficulty in swallowing food" (Table 2). Results of normal thyroid volume $(<20 \mathrm{~mL})$ and increased thyroid volume are shown in Figure 3. Results of patients with RFS $<7$ and patients with RFS $>7$, which indicated a diagnosis of LPR, are illustrated in Figure 4. In patients with RFS $>7$, the most common finding was thick endolaryngeal mucus ( $\mathrm{n}=31$ ), followed by partial ventricular obliteration $(n=28)$, moderate diffuse la- 


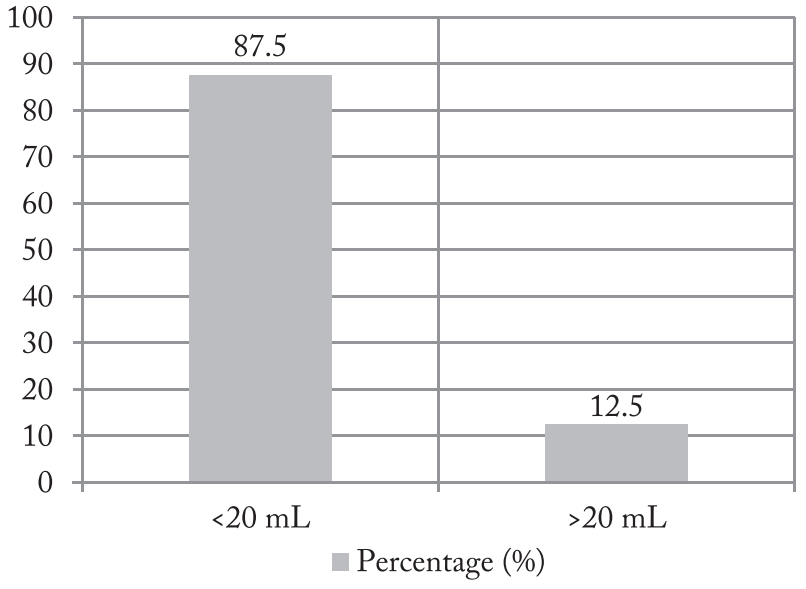

Fig. 3. Patient distribution according to thyroid volume (mL).

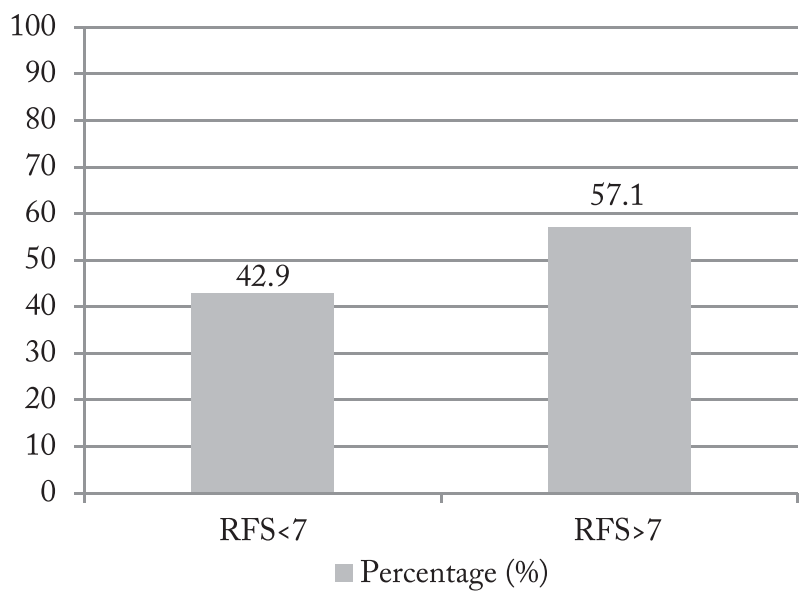

Fig. 4. Patient distribution according to Reflux Finding Score $(R F S)<7$ and $R F S>7$.

ryngeal edema $(n=24)$, erythema/hyperemia of arytenoids $(n=21)$ and moderate vocal cord edema $(n=20)$. There was a statistically significant difference between patients with normal thyroid volume and those with large thyroid volume $(\mathrm{p}<0.001)$, but there was no such difference between patients with RFS $<7$ and RFS $>7$ $(\mathrm{p}=0.13)$.

\section{Discussion}

Although globus pharyngeus often appears as a clinical symptom because of its multifactorial and insufficiently examined etiology, the globus symptom is usually treated inappropriately. Many conditions have been considered in its causation, including cervical osteophytes ${ }^{33}$, cricopharyngeal spasm ${ }^{24}$, cervical heterotopic gastric mucosa $\mathrm{a}^{34,35}$ and retroverted epiglottis ${ }^{36}$. The importance of this study is in the use of GETS as the subjective expression of the globus severity. It can be used in primary care to identify patients for whom referral to secondary care may be appropriate ${ }^{37,38}$. Ali et al. ${ }^{37}$ report that out of ten throat symptoms, globus patients most commonly complained of "Coughing to clear the throat", "Catarrh down the throat" and "Discomfort/irritation in the throat". Similar to our results, Deary et al. ${ }^{28}$ showed that the commonest throat symptoms were "Feeling of something stuck in the throat", "Discomfort/irritation in the throat" and "Want to swallow all the time". One of the aims of our study was to investigate the relationship of the size of the thyroid with the globus symptom. For this purpose, total thyroid volume was observed in all patients. Burns and Timon ${ }^{1}$ showed that one-third of patients with a thyroid mass complained of a globus-type symptom preoperatively. Globus symptom improved or resolved in the majority of patients within six months of surgery. For the first time, they demonstrated a statistically significant improvement in globus symptom in patients in which histologic analysis of the removed thyroid specimen showed an inflammatory response. However, resolution was independent of thyroid size. Our results would tend to support these observations, indicating that a minor proportion of $\mathrm{pa}-$ tients had enlarged thyroid. Some other reports also conclude that thyroidectomy could improve globus symptoms ${ }^{39-41}$. Belafsky et al. ${ }^{30}$ have developed the Reflux Finding Score (RFS) as a useful tool for assessment of LPR patients. Based on their analysis, one can be $95 \%$ certain that the patient with RFS $\geq 7$ will have LPR. In their prospective study, Patigaroo et al. ${ }^{42}$ presented patients diagnosed as LPR cases on the basis of RFS. The most common laryngeal finding was erythema/hyperemia, followed by ventricular obliteration and posterior commissure hypertrophy. Park et al. ${ }^{15}$ assessed the validity of RFS as a diagnostic method for LPR among globus patients. They showed that RFS had low specificity, suggesting that it may not be a valid diagnostic tool for LPR in patients with globus. Although we found no statistically significant difference between patients with RFS $<7$ and RFS $>7$, we did find that more patients had RFS $>7$ (57\%), meaning that they were diagnosed with LPR. Book et al. ${ }^{29}$ 
confirmed that $94.9 \%$ of 157 patients with LPR had globus sensation. Patigaroo et al. ${ }^{42}$ showed that globus pharyngeus was the most common symptom present in 74\% of patients with LPR.

In conclusion, based on our findings, the incidence and severity of globus pharyngeus do not definitely indicate LPR but it is more common in patients with a normal thyroid volume. Our results should be confirmed in a larger population-based study, especially with more male patients. The problem is inadequate recognition of the globus by general practitioners and the importance of specialist treatment. In further investigations, much more patients with globus pharyngeus should be included and symptoms from GETS put in correlation with thyroid pathology and LPR.

\section{References}

1. Burns P, Timon C. Thyroid pathology and the globus symptom: are they related? A two-year prospective trial. J Laryngol Otol. 2007;121:242-5, doi: 10.1017/S0022215106002465

2. Lee BE, Kim GH. Globus pharyngeus: a review of its etiology, diagnosis and treatment. World J Gastroenterol. 2012;18 (20):2462-71, doi: 10.3748/wjg.v18.i20.2462

3. Rowley H, O'Dwyer TP, Jones AS, Timon C. The natural history of globus pharyngeus. Laryngoscope. 1995;105:1118-21, doi: 10.1288/00005537-199510000-00019

4. Moloy PJ, Charter R. The globus symptom. Incidence, therapeutic response, and age and sex relationships. Arch Otolaryngol. 1982;108:740-4.

5. Drossman DA, Li Z, Andruzzi E, et al. U.S. householder survey of functional gastrointestinal disorders. Prevalence, sociodemography, and health impact. Dig Dis Sci. 1993;38:1569-80.

6. Batch AJ. Globus pharyngeus (Part I). J Laryngol Otol. 1988;102:152-8.

7. Harar RP, Kumar S, Saeed MA, Gatland DJ. Management of globus pharyngeus: review of 699 cases. J Laryngol Otol. 2004;118:522-7, doi: 10.1258/0022215041615092

8. Purcell J. A Treatise of Vapours or Hysteric Fits. $2^{\text {nd }}$ ed. London: Edward Place; 1707. pp. 72-4.

9. Malcomson KG. Globus hystericus vel pharyngis (a recommaissance of proximal vagal modalities). J Laryngol Otol. 1968;82:219-30.

10. Hill J, Stuart RC, Fung HK, Ng EK, et al. Gastroesophageal reflux, motility disorders, and psychological profiles in the etiology of globus pharyngis. Laryngoscope. 1997;107:1373-7.

11. Chevalier JM, Brossard E, Monnier P. Globus sensation and gastroesophageal reflux. Eur Arch Otorhinolaryngol. 2003; 260:273-6, doi: 10.1007/s00405-002-0544-0
12. Wilson JA, Pryde A, Piris J, et al. Pharyngoesophageal dysmotility in globus sensation. Arch Otolaryngol Head Neck Surg. 1989;115:1086-90.

13. Koufman JA, Amin MR, Panetti M. Prevalence of reflux in 113 consecutive patients with laryngeal and voice disorders. Otolaryngol Head Neck Surg. 2000;123:385-8, doi: $10.1067 / \mathrm{mhn} .2000 .109935$

14. Oridate N, Nishizawa N, Fukuda S. The diagnosis and management of globus: a perspective from Japan. Curr Opin Otolaryngol Head Neck Surg. 2008;16:498-502, doi: 10.1097/MOO.0b013e328313bb69

15. Park KH, Choi SM, Kwon SU, Yoon SW, Kim SU. Diagnosis of laryngopharyngeal reflux among globus patients. Otolaryngol Head Neck Surg. 2006;134:81-5, doi: 10.1016/j.otohns.2005.08.025

16. Koufman JA. The otolaryngologic manifestations of gastroesophageal reflux disease (GERD): a clinical investigation of 225 patients using ambulatory 24 -hour $\mathrm{pH}$ monitoring and an experimental investigation of the role of acid and pepsin in the development of laryngeal injury. Laryngoscope. 1991;101:1-78.

17. Koufman J, Sataloff RT, Toohill R. Laryngopharyngeal reflux: consensus conference report. J Voice. 1996;10:215-6.

18. Tokashiki R, Funato N, Suzuki M. Globus sensation and increased upper esophageal sphincter pressure with distal esophageal acid perfusion. Eur Arch Otorhinolaryngol. 2010;267: 737-41, doi: 10.1007/s00405-009-1134-1

19. Farkilla MA, Ertama L, Katila H, et al. Globus pharyngis, commonly associated with esophageal motility disorders. Am J Gastroenterol. 1994;89:503-8.

20. Corso MJ, Pursnani KG, Mohiuddin MA, et al. Globus sensation is associated with hypertensive upper esophageal sphincter but not with gastroesophageal reflux. Dig Dis Sci. 1998; 43:1513-7

21. Puhakka HJ, Kirveskari P. Globus hystericus: globus syndrome? J Laryngol Otol. 1988;102:231-4.

22. Batch AJ. Globus pharyngeus: (Part II), Discussion. J Laryngol Otol. 1988;102:227-30.

23. Lee JW, Song CW, Kang CD, et al. Pharyngoesophageal motility in patients with globus sensation. Korean J Gastroenterol. 2000;36:1-9.

24. Timon C, O’Dwyer T, Cagney D, Walsh M. Globus pharyngeus: long-term follow-up and prognostic factors. Ann Otol Rhinol Laryngol. 1991;100:351-4.

25. Cathcart R, Wilson JA. Lump in the throat. Clin Otolaryngol. 2007;32:108-10.

26. Wareing M, Elias A, Mitchell D. Management of globus sensation by the speech therapist. Logoped Phoniatr Vocol. 1997;22:39-42.

27. Deary IJ, Wilson JA, Kelly SW. Globus pharyngis, personality, and psychological distress in the general population. Psychosomatics. 1995;36:570-7.

28. Deary IJ, Wilson JA, Harris MB, MacDougall G. Globus pharyngis: development of a symptom assessment scale. J Psychosom Res. 1995;39:203-13. 
29. Book DT, Rhee JS, Toohill RJ, Smith TL. Perspectives in laryngopharyngeal reflux: an international survey. Laryngoscope. 2002;112:1399-406, doi: 10.1097/00005537-200208000-00014

30. Belafsky PC, Postma GN, Koufman JA. Validity and reliability of the Reflux Symptom Index (RSI). J Voice. 2002;16:274-7.

31. Kawamura O, Aslam M, Rittmann T, Hofmann C, Shaker R. Physical and $\mathrm{pH}$ properties of gastroesophagopharyngeal refluxate: a 24-hour simultaneous ambulatory impedance and $\mathrm{pH}$ monitoring study. Am J Gastroenterol. 2004;99:1000-10, doi: 10.1111/j.1572-0241.2004.30349

32. Brunn J, Block U, Ruf G, Bos I, Kunze WP, Scriba PC. Volumetric analysis of thyroid lobes by real-time ultrasound. Dtsch Med Wochenschr. 1981;106:1338-40.

33. Maran A, Jacobson I. Cervical osteophytes presenting with pharyngeal symptoms. Laryngoscope. 1971;81:412-7.

34. Lancaster JL, Gosh S, Sethi R, Tripathi S. Can heterotopic gastric mucosa present as globus pharyngeus? J Laryngol Otol. 2006;120:575-8, https:// doi.org/10.1017/S0022215106001307

35. Alaani A, Jassar P, Warfield AT, et al. Heterotopic gastric mucosa in the cervical oesophagus (inlet patch) and globus pharyngeus - an under-recognised association. J Laryngol Otol. 2007;121: 885-8, https://doi.org/ 10.1017/S0022215106005524

36. Agada FO, Coatesworth AP, Grace AR. Retroverted epiglottis presenting as a variant of globus pharyngeus. J Laryngol Otol. 2007;121:390-2, doi: 10.1017/S0022215106003422
37. Ali KH, Wilson JA. What is the severity of globus sensation in individuals who have never sought health care for it? J Laryngol Otol. 2007;121:865-8, doi: 10.1017/S0022215106003380

38. Kortequee S, Karkos PD, Atkinson H, Sethi N, et al. Management of globus pharyngeus. Int J Otolaryngol. 2013;2013: 946780, doi: 10.1155/2013/946780

39. Marshall JN, McGann G, Cook JA, Taub N. A prospective controlled study of high-resolution thyroid ultrasound in $\mathrm{pa}^{-}$ tients with globus pharyngeus. Clin Otolaryngol Allied Sci. 1996;21:228-31, https://doi.org/10.1111/j.1365-2273.1996.tb01731

40. Maung KH, Hayworth D, Nix PA, Atkin SL. Thyroidectomy does not cause globus pattern symptoms. J Laryngol Otol. 2005;119:973-5, doi: 10.1258/002221505775010760

41. Consorti F, Mancuso R, Mingarelli J, Pretore E, et al. Frequency and severity of globus pharyngeus symptoms in patients undergoing thyroidectomy: a pre-post short term cross-sectional study. BMC Surgery. 2015;15:53, https://doi.org/10.1186/s12893-015-0037

42. Patigaroo SA, Hashmi SF, Hasan SA, Ajmal MR, Mehfooz N. Clinical manifestations and role of proton pump inhibitors in the management of laryngopharyngeal reflux. Indian J Otolaryngol Head Neck Surg. 2011;63(2):182-9, doi: 10.1007/s12070-011-0253-3

Sažetak

\title{
FARINGEALNI GLOBUS - SIMPTOM POVEĆANE ŠTITNJAČE ILI LARINGOFARINGEALNOG REFLUKSA?
}

\author{
S. Penovic, Ž. Roje, D. Brdar, S. Gračan, A. Bubic, J. Vela i A. Punda
}

Cilj ovoga rada bio je utvrditi povezanost između faringealnog globusa i laringofaringealnog refluksa te između globusa i volumena štitnjače. U dvogodišnje prospektivno istraživanje bilo je uključeno 56 ispitanika u dobi od 18 do 75 godina sa simptomom globusa. Prikupljani su antropometrijski, klinički i laboratorijski podatci o ispitanicima. Svi ispitanici su ispunili upitnik Glasgow Edinburgh Throat Scale (GETS), a potom im je napravljen ultrazvuk štitnjače. Direktnom laringoskopijom su prikazane morfološke promjene na grkljanu koje su validirane kao Reflux Finding Score (RFS). Ako je RFS bio > 7, postavljena je dijagnoza laringofaringealnog refluksa i uvedena terapija inhibitorom protonske crpke. U odnosu na GETS, utvrđena je značajna razlika između ispitanika s normalnim volumenom i povećanim volumenom štitnjače. Nije bilo statistički značajne razlike u pojavnosti faringealnog globusa između ispitanika s RFS $<7$ i onih s RFS $>7$. Prema rezultatima našega istraživanja pojavnost i izraženost faringealnog globusa ne ukazuje nedvomisleno na laringofaringealni refluks. Češće se javlja u bolesnika s normalnim volumenom štitnjače.

Ključne riječi: Laringofaringealni refuks; Bolesti farinksa; Štitnjača; Ultrazvuk; Inbibitor protonske crpke; Ankete i upitnici 